\title{
Temperature mapping of trucks transporting fertile eggs and day-old chicks: Efficiency and/or acclimatization?
}

\author{
Aérica C. Nazareno ${ }^{1}$, Iran J. O. da Silva ${ }^{2}$, Frederico M. C. Vieira ${ }^{3} \&$ Rofson F. S. Santos ${ }^{4}$
}

Key words:
aviculture
ambience
pre-gate environment
egg transport
day-old chicks transport

\section{Palavras-chave:}

avicultura

ambiência

operações pré-porteira

transportadores de ovos

transporte de pintos de um dia

\begin{abstract}
A B S T R A C T
The aim of this study was to evaluate the thermal profiles of trucks used for transporting fertile eggs and day-old chicks. This study was carried out in a broiler hatchery in the State of Sao Paulo. The experiment was conducted during three months, in which six egg loads and 11 chick loads were observed. Thermal profile assessments were performed in an environmental controlled trucks with thermal control and following dimensions: 7.5 x 2.6 x $2.5 \mathrm{~m}$ for eggs, and $8.0 \times 2.5 \times 2.5 \mathrm{~m}$ for chicks. The maximum transport capacities were approximately of 592 boxes of eggs and 630 boxes of chicks, distributed all over the lorry. The thermal profiles were assessed at five-minutes-interval for eggs and in ten-minutesinterval for chicks, using thermal variables such as temperature, relative humidity and specific enthalpy. Geostatistics was used to model spatial dependency (by kriging). The results showed that the acclimatization in trucks was deficient. The loads were found to be submitted to an incompatible temperature, showing a huge thermal variety in the body trucks.
\end{abstract}

\section{Mapeamento térmico de caminhões de ovos férteis e pintos de um dia: Eficiência e/ou climatização?}

\begin{abstract}
R E S U M O
Objetivou-se, com este estudo, avaliar os perfis térmicos de caminhões baús utilizados para o transporte de ovos férteis e pintos de um dia. A pesquisa foi realizada em uma integradora comercial de frangos de corte, no estado de São Paulo. Os períodos experimentais foram de três meses acompanhando 6 carregamentos de ovos e 11 carregamentos de pintos. Foram realizadas avaliações dos perfis térmicos dos caminhões de transporte de ovos férteis e pintos de um dia, do tipo baú, apresentando as seguintes dimensões: 7,5 x 2,6 x 2,5 m para os ovos e $8 \times 2,5 \times 2,5 \mathrm{~m}$ para os pintos os quais eram climatizados. As capacidades máximas de transportes foram de aproximadamente 592 caixas de ovos e 630 caixas de pintos, distribuídas na área da carroceria. As avaliações dos perfis térmicos dos baús foram realizadas em intervalos de $5 \mathrm{~min}$ para os ovos e $10 \mathrm{~min}$ para os pintos por meio dos registros das variáveis térmicas: temperatura, umidade relativa e entalpia específica. A análise estatística foi realizada através da modelagem geoestatística (krigagem). Com base nos resultados verificou-se que a climatização dos caminhões baús avaliados foi deficiente. Os condicionamentos térmicos das cargas estiveram totalmente fora das condições ideais apresentando grandes variações térmicas ao longo dos baús transportadores.
\end{abstract}

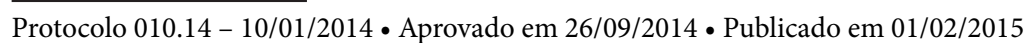

${ }^{1}$ NUPEA/ESALQ/USP. Piracicaba, SP. E-mail: aericacn@yahoo.com.br (Autora correspondente)

${ }^{2}$ NUPEA/ESALQ/USP. Piracicaba, SP. E-mail: iranoliveira@usp.br

${ }^{3}$ UTFPR. Dois Vizinhos, PR. E-mail: fredericovieira@utfpr.edu.br

${ }^{4}$ NUPEA/ESALQ/USP. Piracicaba, SP. E-mail: rofson@yahoo.com 


\section{INTRODUCTION}

The logistics of live load in Brazil, specifically in the aviculture sector, faces various problems related to the lack of information and not enough truck standardization for transporting birds in a comfortable temperature. In fact, the acclimatization efficiency in live loads must be considered as something crucial in the logistics. But, what is truck acclimatization? And how can it be done when transporting live loads? Trucks for transporting fertile eggs and day-old chicks are not projected adequately in order to give thermal comfort conditions to the loads. Many problems have been detected, such as, thermal homogeneity and ventilation in day-old chicks transporting trucks, in which part of the problem is attributed to the size increase of vehicles (Quin \& Baker, 1997) as well as problems related to thermal heterogeneity in transporting fertile eggs (Anderson et al., 2008; Nazareno et al., 2013).

Companies, which produce trucks, should be aware of losses attributed to inadequate transport or/and operations executed in the wrong manner in the pre-gate ambience phase. It is worth noting to mention that in 2011 Brazil lost 230 million reais due to problems in transporting fertile eggs (Nazareno et al., 2013). In regard of losses in the day-old chick transport, the problems are likely to be related to mortality, culling or disposal due to inadequate transportation. Based on this fact, the national broiler sector lost 47.6 million reais in 2010 (Camargo, 2011).

Given the seriousness of this issue, it was possible to observe that there is a lack of studies on logistics in live load transport, since innumerous studies are focused on problems in the "pregate ambience" (Hadara et al., 2011) and in the well-being of the animals (Koknaroglu \& Akunal, 2013). Other recent researches have been done in the "post-gate ambience" (Simões et al., 2009; Vieira et al., 2013), therefore, information related to the fertile egg and day-old chick transport phase is scarce.

Since these technological gaps are identified and, consequently, the correction of the main critical points in the pre-gate phase is urged, it is believed that these are crucial points to be considered as essentials to broiler production with a high quality. The aim of this study was to evaluate the thermal profiles of the trucks used in fertile eggs and day-old chicks transport.

\section{Material AND Methods}

This study was carried out in a broiler hatchery in the State of Sao Paulo, Brazil (22 25' 55" S, 46 57' 28" W; atmospheric pressure of $762 \mathrm{~mm} \mathrm{Hg}$ at $632 \mathrm{~m}$ above sea level). The experiment took three months, in which six egg loads and 11 day-old chick loads were monitored during spring and summer. To transport fertile eggs, a thermal profile in the truck (Constellation Model 26-370 6 x 4 tractor, Volkswagen) was performed. The three-axis-truck presented the following dimensions: $7.5 \mathrm{~m}$ in length; $2.6 \mathrm{~m}$ in width and $2.6 \mathrm{~m}$ in height. The pressure on tires was 100 pounds, and the truck suspension had parabolic springs and hydraulic shock absorbers of double action. The acclimatization equipment was regulated in $23{ }^{\circ} \mathrm{C}$ (dry bulb temperature) and in $80 \%$ (relative humidity).
The load capacity of the truck was approximately 592 boxes of eggs which were stacked and distributed inside the lorry. However, the analyzed loads presented 444 boxes as average, in which piles of 6 boxes were made inside of the lorry. The boxes had the following dimensions: $63 \times 32.5 \times 30 \times 3 \mathrm{~cm}$ (external area), $3.2 \times 1.1 \mathrm{~cm}$ (side opening) and $2 \times 2 \mathrm{~cm}$ (bottom). These boxes carried 240 eggs, the equivalent of 8 plastic crates $(30 \times 30$ $\mathrm{cm}$ ) for 30 eggs. During the months of August and September, six monitored trips were done by the driver in the same road, where the truck traveled $60 \mathrm{~km}$.

In order to characterize the thermal ambience of the truck, variables were recorded such as temperature $\left(\mathrm{T},{ }^{\circ} \mathrm{C}\right)$ and relative humidity (RH, \%) by using 18 dataloggers (Onset, model Hobo ${ }^{\circ}$ ) distributed along the lorry in 1-minute interval.

For the day-old chick transport, a two-axis-truck (Constellation model - 26-370 $6 \times 4$ tractor, Volkswagen) presenting the following dimensions: $8 \times 2.5 \times 2.5 \mathrm{~m}$, was used. The lorry had both internal and external area coated with aluminum with thermal isolation of expanded polyurethane. The doors were constituted of 3 layers thoroughly sealed with stainless steel. There were 3 rows (left, right and center) with $0.7 \mathrm{~m}$ of spacing. The sides were divided with 2 shelves, with vertical spacing approximately of $0.81 \mathrm{~m}$ among themselves.

The internal temperature, ventilation and humidity were controlled by sensors, and the humidity in the interior of the load was done by centrifugal humidifier or by pressurized air nozzles, in which they were controlled by an electronically digital system installed in truck cab. The thermal control was programmed for the following conditions: temperature between 23 and $25^{\circ} \mathrm{C}$, and relative humidity between 60 and $70 \%$. The acclimatization system was located in the front of the lorry, once the ventilation was distributed through the floor openings, and the air exits (ventilation) were located in the truck louver (openings of the roof). It is worth noting that the acclimatization system was only turned on when the truck was in movement. Figure 1 shows pictures of the acclimatized transport truck loaded with fertile eggs and day-old chicks.

The boxes used for transporting present the following measures: $42 \times 57 \times 15 \times 2.5 \mathrm{~cm}$. They have 26 openings around the box $(1 \times 6.5 \mathrm{~cm})$ that are stacked with the others, in which the last one has a cover full of holes, for minimum air circulation so that animals do not suffer during the trip. There were 4 boxes (maximum number) in each stack found in the superior shelf, 6 boxes in the shelf from the middle, and 6 boxes in the inferior shelf in each side. The load capacity was 480

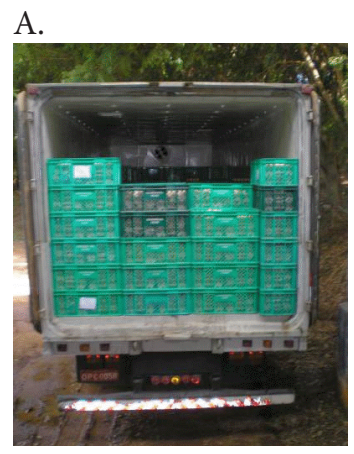

B.

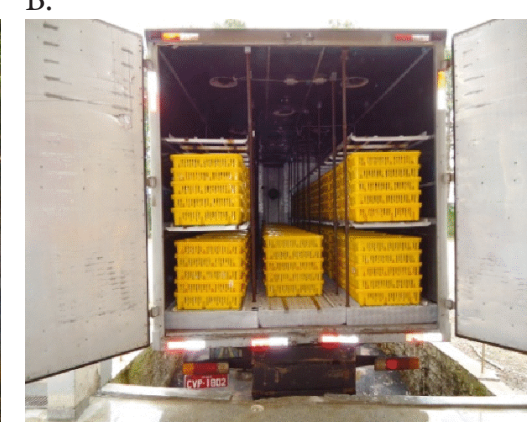

Figure 1. Types of acclimatized transport trucks loaded with fertile eggs (A) and day-old chicks (B) used in this study 
boxes in the shelves and 150 boxes in the corridor, totalizing 630 boxes with 100 chicks each. There was an available area of $23.94 \mathrm{~cm}^{2}$ for each animal inside of each box.

To characterize the thermal ambience, thermal variables such as room temperature $\left(\mathrm{T} ;{ }^{\circ} \mathrm{C}\right)$ and relative humidity $(\mathrm{RH}$; $\%$ ) were recorded by using 18 dataloggers (Onset, model Hobo $^{\varpi}$ ), spread all over the lorry, programmed to register all data in a ten-minute-interval.

The temperature values, relative humidity and the local atmospheric pressure $(761.98 \mathrm{mmHg})$ were used for calculating the specific enthalpy (h; $\mathrm{kJ} \mathrm{kg}^{-1}$ dry air), through the equation proposed by Rodrigues et al. (2011).

Geostatistics (kriging) was used to modeling spatial dependency of temperature, relative humidity and specific enthalpy in order to obtain the other points in the lorry as well as the spatial dependency assessment of the variables, taking into account the interior of the lorry using $\mathrm{GS}^{+} 7.0$ (Robertson, 2000).

Descriptive and exploratory statistical analysis was used to analyze the data found through this study in order to verify the presence of discrepancy points (outliers). In geostatistics, these values caused a strong impact, mainly in the beginning of the semivariogram. This fact can lead to wrong conclusions about the noise in the variance (nugget effect) and/or the existence of spatial correlation.

The adjustments of theoretical models (spherical, exponential and Gaussian) was found through the semivariogram calculation. It can be observed in the Eq. 1 proposed by Vieira (2000):

$$
\hat{\gamma}(\mathrm{h})=\frac{1}{2 \mathrm{~N}(\mathrm{~h})} \sum_{\mathrm{i}=1}^{\mathrm{N}(\mathrm{h})}[\mathrm{Z}(\mathrm{xi})-\mathrm{Z}(\mathrm{xi}+\mathrm{h})]^{2}
$$

in which:

$\mathrm{N}$ (h) - number of experimental pairs of observations $\mathrm{Z}$ (xi) and $\mathrm{Z}(\mathrm{xi}+\mathrm{h})$ separated by a distance $\mathrm{h}$

The semivariogram is represented by the graphic $\gamma(\mathrm{h})$ versus (h).

The coefficients of the theoretical model are estimated to the semivariogram nugget effect $\left(C_{0}\right)$, level $\left(C_{0}+C_{1}\right)$, structural component $\left(\mathrm{C}_{1}\right)$ and spatial dependence (a) as a result of an adjustment from a mathematical model of $\gamma(\mathrm{h})$ values.

To the semivariograms the following coefficients were estimated: nugget effect $\left(\mathrm{C}_{0}\right)$, level $\left(\mathrm{C}_{0}+\mathrm{C}_{1}\right)$, structural component $\left(\mathrm{C}_{1}\right)$ and the spatial dependency (a). The choice of the best model was based on the smallest sum of square residuals (SSR) and multiple coefficient of determination $\left(\mathrm{R}^{2}\right)$. In the sequence, the $\mathrm{R}^{2}$ of the cross-validation $\left(\mathrm{R}^{2}-\mathrm{VC}\right)$ (observed values versus estimated values) was used. In order to analyze the spatial dependence index (SDI) of the attributes, a definite relation in the program $\mathrm{GS}^{+}\left(\mathrm{C}_{1} / \mathrm{C}_{0}+\mathrm{C}_{1}\right)$ and the intervals proposed by Zimback (2001), was used. This relation considers that weak spatial dependence (SDI $\leq 25 \%)$; moderate $(25 \%<\mathrm{SDI}<75 \%)$ or strong (SDI $\geq 75 \%)$.

Moreover, in order to adjust the theoretical models and the definition of the coefficients to the semivariograms, an estimative method of values distributed in space using adjacent values (Kriging) was used. This method is based on estimating moving averages (Landim, 1998).

\section{Results AND Discussion}

Through the results of the geostatistical analysis for the transport of fertile eggs, it was possible to observe that all the microclimatic variables presented spatial dependence in all thermal profile of the truck (Table 1).

The profile temperature of the acclimatized lorry was adjusted to the exponential model with $\mathrm{R}^{2}$ and reach of 0.35 and $3.06 \mathrm{~m}$, respectively. The relative humidity and specific enthalpy were adjusted by the Gaussian model with $\mathrm{R}^{2}$ of 0.64 and 0.77 , and reach of 6.05 and $7.00 \mathrm{~m}$, respectively, reflecting the continuity of the studied variables. These microclimatic variables also presented a strong spatial dependence (SDI $\geq 75 \%$ ) with SDI values of 83.85 and $92 \%$, according to the limits established by Zimback (2001), showing that the thermal profiles of the acclimatized lorry in the transport of fertile eggs were heterogeneous and presented high thermal range.

In relation to Table 1 , it was possible to observe that the spatial distributions of the thermal profiles in the transport of day-old chicks, in which the temperature variables, relative humidity and specific enthalpy were adjusted by the Gaussian and spherical models with $\mathrm{R}^{2}$ of $0.40,0.50,0.65$, and reaches of $2.07,1.34,2.70 \mathrm{~m}$, respectively. Also, it was verified that the temperature and the relative humidity obtained a strong spatial dependence (SDI $\geq 75 \%$ ), presenting a SDI of 84 and $89 \%$. However, the only variable that showed a moderated spatial dependence was the specific enthalpy $(25 \%<$ SDI $<$ $75 \%$ ), with SDI value of $70 \%$, according to the limits established by Zimback (2001). Hence, it means that the thermal profiles of the acclimatized lorry in the transport of day-old chicks presented heterogeneity, reflecting in huge thermal amplitudes.

The thermal profiles of the acclimatized truck diagnosed a heterogeneous environment through temperature, relative

Table 1. Model and parameters estimated from experimental semivariograms for the microclimatic variables: temperature $(\mathrm{T})$, relative humidity $(\mathrm{RH})$ and enthalpy $(\mathrm{h})$ in transport of fertile eggs and day-old chicks

\begin{tabular}{|c|c|c|c|c|c|c|}
\hline & \multicolumn{3}{|c|}{ Truck with fertile eggs } & \multicolumn{3}{|c|}{ Truck with day-old chicks } \\
\hline & $\mathrm{T}\left({ }^{\circ} \mathrm{C}\right)$ & RH (\%) & h (kJ kg-1 dry air) & $\mathrm{T}\left({ }^{\circ} \mathrm{C}\right)$ & RH (\%) & h (kJ kg-1 dry air) \\
\hline $\mathrm{R}^{2}$ & 0,35 & 0,64 & 0,77 & 0,40 & 0,50 & 0,65 \\
\hline $\mathrm{C}_{0}$ & 0,31 & 97,78 & 4,80 & 1,04 & 43,00 & 42,8 \\
\hline$\left(\mathrm{C}_{0}+\mathrm{C}_{1}\right)$ & 1,81 & 656,90 & 60,8 & 6,41 & 394,00 & 135,30 \\
\hline $\mathrm{C}_{1}$ & 1,50 & 559,12 & 56,00 & 5,37 & 351,00 & 92,50 \\
\hline EDI (\%) & 83 & 85 & 92 & 84 & 89 & 70 \\
\hline Reach (m) & 3,06 & 6,05 & 7,00 & 2,07 & 1,34 & 2,70 \\
\hline Model & Exponential & Gaussian & Gaussian & Gaussian & Spherical & Spherical \\
\hline
\end{tabular}

$\mathrm{C}_{0}$ - pepita effect, $\left(\mathrm{C}_{0}+\mathrm{C}_{1}\right)$ - patamar, $\mathrm{C}$ - structural component, $\mathrm{EDI}$ - spatial dependence index 
humidity and specific enthalpy to transport fertile eggs. The variables showed: AT (room temperature) $=6^{\circ} \mathrm{C}, \mathrm{ARH}$ (relative room humidity) $=50 \%$ and $\mathrm{Ah}$ (room enthalpy) $=25 \mathrm{~kJ} \mathrm{~kg}^{-1}$ dry air (Figure 2).

The temperature of the truck of the fertile eggs was above the recommended level (between $10-20{ }^{\circ} \mathrm{C}$ ) by Fasenko et al. (1991), Elibol \& Brake (2008), Nazareno et al. (2013). The major thermal nucleus was identified in the rear region of the lorry $\left(25-27^{\circ} \mathrm{C}\right)$ and in the front of the lorry $\left(23-25^{\circ} \mathrm{C}\right)$. Therefore, the rear and the front regions near to the acclimatizer were the most problematic ones. According to Damron et al. (1994); Gast \& Holt (2000); Anderson et al. (2008); Oviedo-Rondón et al. (2009), similar results to these were found in commercial transport of eggs.

The relative humidity of the lorry respected the recommended level (55 to 75\%) by Fasenko et al. (1991); Fiúza et al. (2006); Araújo et al. (2009); Nazareno et al. (2013) in the majority of the profile. However, the center of the lorry

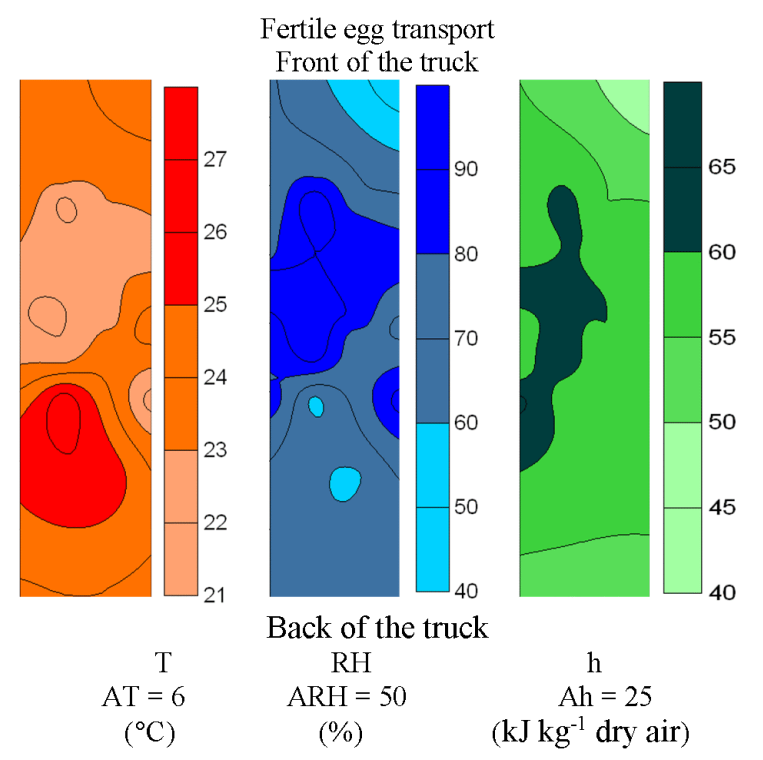

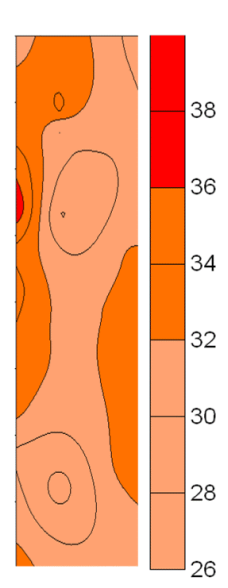

Day-old chick transport

Front of the truck

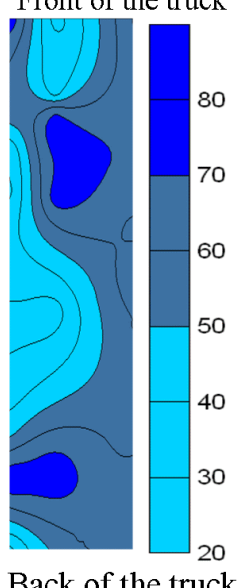

Back of the truck

$$
\mathrm{RH}
$$

$\mathrm{ARH}=40$

$(\%)$

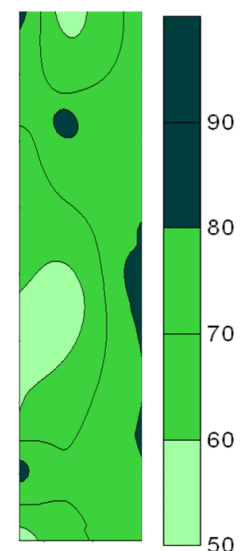

$\mathrm{h}$

$\mathrm{Ah}=40$

( $\mathrm{kJ} \mathrm{kg}^{-1}$ dry air)
Figure 2. Thermal profile spatial distribution of the variables: temperature $(T)$, relative humidity $(R H)$ and specific enthalpy (h) during the fertile egg and day-old chick transport with their respective amplitude of temperature $(A T)$, relative humidity $(A R H)$ and specific enthalpy (Ah) showed the major thermal nucleus (80-90\%), meanwhile the smallest thermal core was found near to the acclimatizer (60$40 \%)$. Since the relative humidity was found above the level, condensation upon the eggs could have started which it would imply to an environment more susceptible to the growth of microorganisms (fungus and bacteria) in fertile eggs (Baracho et al., 2010; Freitas et al., 2011).

Through the specific enthalpy, it was possible to observe that the only region near to acclimatizer $\left(40-50 \mathrm{~kJ} \mathrm{~kg}^{-1}\right.$ dry air) was inside the ideal levels $\left(25-44.7 \mathrm{~kJ}^{-1} \mathrm{~kg}\right.$ dry air) for the atmospheric pressure of $761.98 \mathrm{~mm} \mathrm{Hg}$. This aspect is an evidence of the thermal heterogeneity all the way on the load of fertile eggs. Similar results to these were found by Damron et al. (1994); Nazareno et al. (2013) during the transport of fertile eggs. It is very important to have the ideal thermal conditions in the lorry, so that loss on the pre-gate environmental control can be decreased during this phase of the transport. When these thermal conditions are not respected in the transport of fertile eggs, which means, they are above the ideal levels, the embryo development is increased before the eggs are incubated, leading to loss in egg hatchability and quality of chicks.

These results provide enough evidences about one of the biggest problems found on fertile egg transportation in Brazil, which is related to the absence of thermal standardization in acclimatized trucks. These trucks are not planned adequately to provide ideal refrigerated conditions to the load.

In the day-old chick transport, it was observed that the microclimatic profiles of the acclimatized lorry (temperature, relative humidity and specific enthalpy) presented a huge heterogeneity in the chick load, obtaining the following thermal amplitudes: $\mathrm{AT}=12{ }^{\circ} \mathrm{C}, \mathrm{ARH}=40 \%$ and $\mathrm{Ah}=40$ $\mathrm{kJ} \mathrm{kg}^{-1}$ dry air (Figure 1).

The temperature inside of the chick boxes was found below the ideal ranges $\left(35-32{ }^{\circ} \mathrm{C}\right)$ as recommended by Lin et al. (2005); Mujahid \& Furuse (2009); Nascimento et al. (2012; 2013). This aspect brings an important clue showing that the chicks suffered cold stress during transportation. The major concern on maintaining the ideal temperature during baby chick transport is connected with the precociousness in the thermoregulation system due to presenting a high tolerance when temperature is high, when compared to a low temperature. This factor shows that there is an ample need on keeping high temperatures on the first moments of life (Dunnington \& Siegel, 1984). It is worth noting that the optimal zootechnical performance of the chicken, in its adult phase, is intrinsically related to the post-hatched chick capacity on regulating its own body temperature efficiently. Hence, it means that birds on the pre-slaughter phase allocated in sheds depend on the development of physiological mechanism standards stimulated by the thermal environment during the baby chick phase (Tzschentke, 2007).

It was verified in the thermal nucleus that small temperatures $\left(26-32{ }^{\circ} \mathrm{C}\right)$ were identified on the front regions all the way to the back of the lorry. Similar results were found by Quinn \& Baker (1997) who assessed day-old chick transport. Also, Damron et al. (1994); Gast \& Holt (2000); Anderson et al. (2008); Nazareno et al. (2013) observed that these same critical regions presented the equivalent results in the thermal profile during egg transportation. 
The best relative humidity regions in the day-old chick transport happened to be found from the back of the truck to a small area in the front of the lorry (50-60\%) as suggested by Lin et al. (2005); Mujahid \& Furuse (2009); Nascimento et al. $(2012 ; 2013)$. However, it was possible to observe some critical regions in the lorry that presented nucleus with relative humidity out of the ideal ranges $(20-50 \%$ and $70-80 \%)$. These regions showed the existence of thermal heterogeneity in this profile, which can be attributed to a low efficient air circulation system found on the lorry. In addition, Quinn \& Baker (1997) verified that these same critical regions in the chick load were related to the low efficient air circulation system of the truck, making it heterogeneous. Moreover, it was verified the same results in egg transport (Damron et al., 1994; Gast \& Holt, 2000; Anderson et al., 2008).

Relative humidity plays a major role in heat exchange (sensible and latent heat) on chicks (Lin et al., 2005; Schimidt et al., 2009; Nascimento et al., 2012; 2013). The loss of evaporative heat (latent) increases with temperature, therefore the effect of thermoregulation on bird will depend on air temperature as well as on it age (Lin et al., 2005). The relative humidity values above $60 \%$ reduce the heat transfer from the internal to the external body area, damaging the thermal exchanges between the animal and the environment. However, when the relative humidity is below the range of $50 \%$ the heat exchange between the animal and the ambience by via latent are raised, which may cause the ascitic syndrome, known as pulmonary hypertension syndrome (Mujahid \& Furuse, 2009).

The specific enthalpy profile presented small thermal nucleus located on the front and center area of the lorry. They presented the ideal range $\left(50-60 \mathrm{~kJ} \mathrm{~kg}^{-1} \mathrm{dry}\right.$ air) for the day-old chick with an atmospheric pressure of $761.98 \mathrm{~mm} \mathrm{Hg}$. Quin \& Baker (1997) observed that the most critical regions for day-old chick load were found to be on the front and center areas of the truck. It is likely to have heterogeneous results due to an inefficient ventilation system inside of the truck. The consequences of an inadequate chick transport will only be seen at the farm by the time the chicks cannot reach their optimal scoring on the zootechnical performance during 42 days, in which some of these chicks are disposed and others die in their first week of life.

Based on these data, there is an urge of improving the standards on the acclimatization system of fertile eggs and dayold chicks transport. Since the ambience is completely closed and acclimatized, it was expected to have a bigger homogeneity on the microclimatic characteristics on body trucks.

\section{Conclusions}

1. The acclimatization on the assessed trunk truck was deficient, in which the thermal profiles of the ambience used to transport fertile eggs and day-old chick showed microclimatic variations all over the lorry.

2. The microclimatic conditions were above the ideal range for transporting fertile eggs, while they were bellow for transporting day-old chicks.

\section{Acknowledgments}

The authors thank FAPESP (Research Foundation of São Paulo State) for the financial support to this research and to CNPq and CAPES for granting the scholarship.

\section{Literature Cited}

Anderson, K. E.; Patterson, P. H.; Koelkebeck, K. W.; Darre, M. J.; Carey, J. B.; Ahn, D. U.; Ernst, R. A.; Kuney, D. R.; Jones, D. R. Temperature sequence of eggs from oviposition through distribution: Transportation - Part 3. Poultry Science, v.87, p.11951201, 2008. http://dx.doi.org/10.3382/ps.2007-00236

Araújo, W. A. G.; Alebrante, L.; Castro, A. D. Fatores capazes de afetar os indicies de eclosão. Revista Eletrônica Nutritime, v.6, p.1072-1087, 2009.

Baracho, M. S.; Nääs, I. A.; Gigli, A. C. S. Impacto das variáveis ambientais em incubatório de estágio múltiplo de frangos de corte. Engenharia Agrícola, v.30, p.563-577, 2010. http://dx.doi. org/10.1590/S0100-69162010000400001

Camargo, J. R. Ambiência pré-porteira: O tempo de espera no incubatório e sua influência sobre o desempenho inicial de frangos de corte. Piracicaba: ESALQ/USP, 2011. 189p. Dissertação Mestrado

Damron, B. L.; Douglas, C. R.; Jacobs, R. D. Temperature patterns in commercial egg transport vehicles. Journal of Applied Poultry Research, v.3, p.193-198, 1994. http://dx.doi.org/10.1093/ japr/3.2.193

Dunnington, E. A.; Siegel, P. B. Thermoregulation in newly hatched chicks. Poultry Science, v.63, p.1303-1313, 1984. http://dx.doi. org/10.3382/ps.0631303

Elibol, O.; Brake, J. Effect of egg position during three and fourteen days of storage and turning frequency during subsequent incubation on hatchability of broiler hatching eggs. Poultry Science, v.87, p.12371241, 2008. http://dx.doi.org/10.3382/ps.2007-00469

Fasenko, G. M..; Robinson, F. E.; Armstrong, J. G. Variability in preincubation embryo development in domestic fowl: effects of nest holding time and method o egg storage. Poultry Science, v.70, p.1876-1881, 1991. http://dx.doi.org/10.3382/ps.0701876

Fiúza, M. A.; Lara, L. J. C.; Aguilar, C. A. L.; Ribeiro, B. R. C.; Baião, N. C. Efeitos das condições ambientais no período entre a postura e o armazenamento de ovos de matrizes pesadas sobre o rendimento de incubação. Arquivo Brasileiro de Medicina Veterinária e Zootecnia, v.58, p.408-413, 2006. http://dx.doi.org/10.1590/ S0102-09352006000300019

Freitas, L. W.; Paz, I. C. L. A.; Garcia, R. G.; Caldara, F. R.; Seno, L. O.; Felix, G. A.; Lima, N. D. S.; Ferreira, V. M. O. S.; Cavichiolo, F. Aspectos qualitativos de ovos comerciais submetidos a diferentes condições de armazenamento. Revista Agrarian, v.4, p.66-72, 2011.

Gast, R. K.; Holt, P. S. Influence of the level and location of contamination on the multiplication of Salmonella enteritidis at different storage temperatures in experimentally inoculated eggs. Poultry Science, v.79, p.559-563, 2000. http://dx.doi.org/10.1093/ ps/79.4.559

Hadara, S.; Ghosha, T. K.; Toshiwatia, T. K.; Bedford, M. R. Effects of yeast (Saccharomyces cerevisiae) and yeast protein concentrate on production performance of broiler chickens exposed to heat stress and challenged with Salmonella enteritidis. Animal Feed Science and Technology, v.168, p.61-71, 2011. http://dx.doi.org/10.1016/j. anifeedsci.2011.03.007 
Koknaroglu, H.; Akunal, T. Animal welfare: An animal science approach. Meat Science, v.95, p.821-827, 2013. http://dx.doi. org/10.1016/j.meatsci.2013.04.030

Landim, P. M. B. Análise estatística de dados geológicos. São Paulo: UNESP, 1998. 226p.

Lin, H.; Zhang, H. F.; Jiao, H. C.; Zhao, T.; Sui, S. J.; Gu, X. H.; Zhang, Z. Y.; Buyse, J.; Decuypere, E. Thermoregulation responses of broiler chickens to humidity at different ambient temperatures. I. one week of age. Poultry Science, v.84, p.1166-1172, 2005. http:// dx.doi.org/10.1093/ps/84.8.1166

Mujahid, A.; Furuse, M. Oxidative damage in different tissues of neonatal chicks exposed to low environmental temperature. Comparative Biochemistry and Physiology Part A, v.152, p.604608, 2009. http://dx.doi.org/10.1016/j.cbpa.2009.01.011

Nascimento, S. T.; Silva, I. J. O.; Maia, A. S. C.; Castro, A. C.; Vieira, F. M. C. Mean surface temperature prediction models for broiler chickens-a study of sensible heat flow. International Journal of Biometeorology, v.1, p.1-7, 2013.

Nascimento, S. T.; Silva, I. J. O.; Mourão, G. B.; Castro, A. C. Bands of respiratory rate and cloacal temperature for different broiler chicken strains. Revista Brasileira de Zootecnia, v.41, p.1318-1324, 2012. http://dx.doi.org/10.1590/S151635982012000500033

Nazareno, A. C.; Silva, I. J. O.; Vieira, F. M. C.; Camargo, J. R.; Medeiros, S. R. R. Caracterização do microclima dos diferentes layouts de caixas no transporte de ovos férteis. Revista Brasileira de Engenharia Agrícola e Ambiental, v.17, p.327-332, 2013. http:// dx.doi.org/10.1590/S1415-43662013000300012

Oviedo-Rondón, E. O.; Wineland, M. J.; Small, J.; Cutchin, H.; Mcelroy, A.; Barri, A.; Martin, S. Effect of incubation temperatures and chick transportation conditions on bone development and leg health. Journal of Applied Poultry Research, v.18, p.671-678, 2009. http://dx.doi.org/10.3382/ japr.2008-00135
Quinn, A. D.; Baker, C. J. An investigation of the ventilation of a day-old chick transport vehicle. Journal of Wind Engineering and Industrial Aerodynamics, v.67, p.305-311, 1997. http://dx.doi. org/10.1016/S0167-6105(97)00081-0

Robertson, G. P. GS+: Geostatistics for the environmental sciences GS+ User's Guide. Plainwell: Gamma Desing Software, 2000. 152p.

Rodrigues, V. C.; Silva, I. J. O.; Vieira, F. M. C.; Nascimento, S. T. A correct enthalpy relationship as thermal comfort index for livestock. International Journal of Biometeorology, v.55, p.455459, 2011. http://dx.doi.org/10.1007/s00484-010-0344-y

Schimidt, G. S.; Figueiredo, E. A. P.; Saatkamp, M. G.; Boom, E. R. Effect of storange period and egg weight on embryo development and incubation results. Brazilian Journal of Poultry Science, v.11, p.1-5, 2009.

Simões, G. S; Oba, A.; Matsuo, T.; Rossa, A.; Shimokomaki, M.; Ida, E. I. Vehicle thermal microclimate evaluation during Brazilian summer broiler transport and the occurrence of PSE (pale, soft, exudative) meat. Brazilian Archives of Biology and Technology, v.52, p.195204, 2009. http://dx.doi.org/10.1590/S1516-89132009000700025

Tzschentke, B. Attainment of thermoregulation as affected by environmental factors. Poultry Science, v.86, p.1025-1036, 2007. http://dx.doi.org/10.1093/ps/86.5.1025

Vieira, F. M. C.; Silva, I. J. O.; Barbosa Filho, J. A. D.; Vieira, A. M. C. Reducing pre-slaughter losses of broilers: Crating density effects under different lairage periods at slaughterhouse. Journal of Animal Behaviour Biometeorology, v.1, p.1-6, 2013. http:// dx.doi.org/10.14269/2318-1265.v01n01a01

Vieira, S. R. Geoestatística em estudos de variabilidade espacial do solo. In: Novais, F.; Alvarez, V.; Schaefer, C. E. G. R. (ed.). Tópicos em ciência do solo. Viçosa: Sociedade Brasileira de Ciência do Solo, v.1, 2000. 53p.

Zimback, C. R. L. Análise espacial de atributos químicos de solos para fins de mapeamento da fertilidade. Botucatu: FCA/UNESP, 2001. 114p. Tese Livre-Docência 